\title{
A Research on The Evaluation of Performances After Re- Sharpening of The End Mills
}

\section{Parmak Frezelerin Yeniden Bileme Sonrasi Performanslarinin Değerlendirilmesi Üzerine Bir Araştirma}

\author{
Salih Korucu $1^{*}(\mathbb{0}$, Yasin Hacıbektaşoğlu 2 (ㄷ) \\ ${ }^{1}$ Gazi University, Faculty of Technology, Department of Manufacturing Engineering, Ankara, TURKEY \\ 2,Machine Chemical Industry, Ammunition Factory, Kırıkkale, TURKEY \\ Sorumlu Yazar / Corresponding Author*: skorucu@gazi.edu.tr
}

Geliş Tarihi / Received: 04.03.2021 Araștırma Makalesi/Research Article Kabul Tarihi / Accepted: 25.04.2021 DOI:10.21205/deufmd.2022247023 Atıf sekli/How to cite: KORUCU,S.,HACIBEKTAŞOĞLU,Y.(2022).A Research on The Evaluation of Performances After Re-Sharpening of The End Mills.DEUFMD, 24(70), 247-262

\begin{abstract}
In this study, the performances of end mills used widely in machining were investigated in case of their reuse by sharpening. For this purpose, at the CNC vertical machining center, slot milling processes were carried out with HSS end mills (used once) on the AISI 1050 manufacturing steel having two different diameters and with carbide end mills (again used once) on the AISI D2 (2080) cold work tool steel having two different diameters. Machining experiments were made by using four different cutting speeds, four different feed and four different cutting depths. These end mills, afterwards, were re-sharpened by considering their original tool geometry and the machining experiments were repeated at the same conditions and their performances were evaluated in comparison with the performances of the new tool. In general, wear amounts in the sharpened tools were observed to be higher with respect to the new tools. In the HSS tools, no adverse effect of sharpening process was observed on the machining performance. In the carbide tools, especially from the point of surface quality for the tools having small diameter there is no adverse effect of resharpening and re-sharpening can be recommended with the condition of observing the surface quality in parallel to the increase in diameter.
\end{abstract}

Keywords: Cutting Force, Machining Performance, Re-Sharpening, Surface Roughness, Tool Flank Wear

Öz

$\mathrm{Bu}$ çalışmada, talaşlı imalatta yaygın olarak kullanılan parmak frezelerin, bilenerek tekrar kullanılmaları halindeki performansları araştırılmıştır. Bu amaçla, CNC dik işleme merkezinde, AISI 1050 imalat çeliği üzerinden ilk kez kullanılmış olan iki farklı çapta HSS parmak frezeler ile AISI D2 (2080) soğuk iş takım çeliği üzerinden de yine ilk kez kullanılmış olan iki farklı çapta karbür parmak frezeler ile talaş kaldırma işlemleri yapılmıștır. Talaş kaldırma deneyleri, dört farklı kesme hızı, dört farklı ilerleme ve dört farklı kesme derinliği uygulanarak yapılmıștır. Sonrasında, kullanılan bu parmak frezeler, orijinal takım geometrisi dikkate alınarak yeniden bilenmiş ve aynı şartlarda talaş kaldırma deneyleri tekrarlanarak performansları, yeni takımların performansları ile mukayeseli olarak değerlendirilmiştir. Genel olarak bilenmiş takımlardaki aşınma miktarlarının yeni takımlara 
göre daha yüksek olduğu gözlenmiştir. HSS takımlarda bileme işleminin işleme performansına herhangi bir olumsuz etkisi gözlenmemiştir. Yekpare sementit karbür takımlarda özellikle yüzey kalitesi açısından küçük çaplı takımlar için yeniden bilemenin olumsuz bir etkisi gözlenmezken çaptaki artışa paralel olarak yüzey kalitesindeki beklentilerin izlenmesi kaydı ile yeniden bileme işlemi önerilebilir.

Anahtar Kelimeler: Kesme Kuvveti, İșleme performansı, Yeniden Bileme, Yüzey Pürüzlülüğü, Takım Yanak Aşınması

\section{Introduction}

Nowadays, machining has become a continuously improving and developing sector in order to meet the needs in the fields of defense, agriculture, automotive, medical and space-aeronautics. The main point in machining is to obtain maximum amount of production with low costs and maximum tool life. In doing this, the effects of cutting conditions affecting machining on the tool wear and surface roughness must be analysed to maintain the surface quality. Cutting forces are one of the most important variables being directly affected by any variable created during machining. The variables affecting the cutting forces are cutting speed, feed rate, cutting depth, cutting tool geometry, work piece material, dynamic characteristics of cutting tool-machine tool couple, fixing system of work piece, wear development on the tool cutting surfaces, temperature and vibration. The cutting forces affecting the tool are the important source of information for the condition of tool. This information can be used for the understanding of machinability, tool wear, tool breakdown, chattering and surface integrity [1].

In the machining sector, several processes are carried out to make production with minimum fault and to use the time economically. Milling is one of these processes. Milling is one of the most important machining processes and comprises approximately $25 \%$ of the machining processes and $20 \%$ of the time spent in the machining processes with cutting tools [2]. Surface roughness is the most significant measure specifying the surface quality of the machined parts in the milling processes and depends generally on the result of machining conditions such as tool geometry and cutting conditions. Whereas the cutting forces created during machining, changes the tool-piece position with their effects on the tool and piece and affect the machining quality. In literature there are many studies about surface roughness, cooling in machinability, metal cutting temperature, tool wear, Taguchi method based oprimization, machinability, turning, milling, hard machining cryogenic process and cutting forces [3-25] but there is no study on a research on performances of the reusing of sharpened end mills.

In the machine manufacturing, to minimize the cutting tool cost and to obtain a maximum tool life, the cutting tool must be used with the machining parameters having the most efficient working conditions [18]. All of the cutting tools are worn during machining and this wearing goes on till the end of cutting tool life [26]. The breakdown of cutting tool tip is a very complicated formation due to the effects of different wear mechanisms at the same time [27]. In the recent years owing to "sustainable machining" concept, reuse of cutting tools which complete their life by re-sharpening and coating processes (reconditioning) to decrease the sustainable environment and production input costs is at issue. In the global market, a lot of cutting tool manufacturer makes re-sharpening and have a tendency of expansion. In the same way, even the smaller manufacturers re-sharpen their worn tools with low-cost sharpening devices providing their reuse. Although these companies guaranty the performance of these re-sharpened tools, there is no such study in literature verifying the performance of resharpened tools with respect to the original ones.

In this study, slot milling was applied to two different materials by using different cutting parameters. The purpose of this study is to compare the machining performances of resharpened end mills with the performances of new tools experimentally. In the study, the slot milling performances of two different tool materials (HSS and cementite carbide) having two different diameters ( $\varnothing 5$ and $\varnothing 8 \mathrm{~mm}$ ) on the two different work pieces (AISI 1050 and AISI D2 ) were evaluated on the basis of cutting forces, surface roughness and tool wear. 


\section{Experimental Studies}

Flow chart of the study is shown in Figure 1.

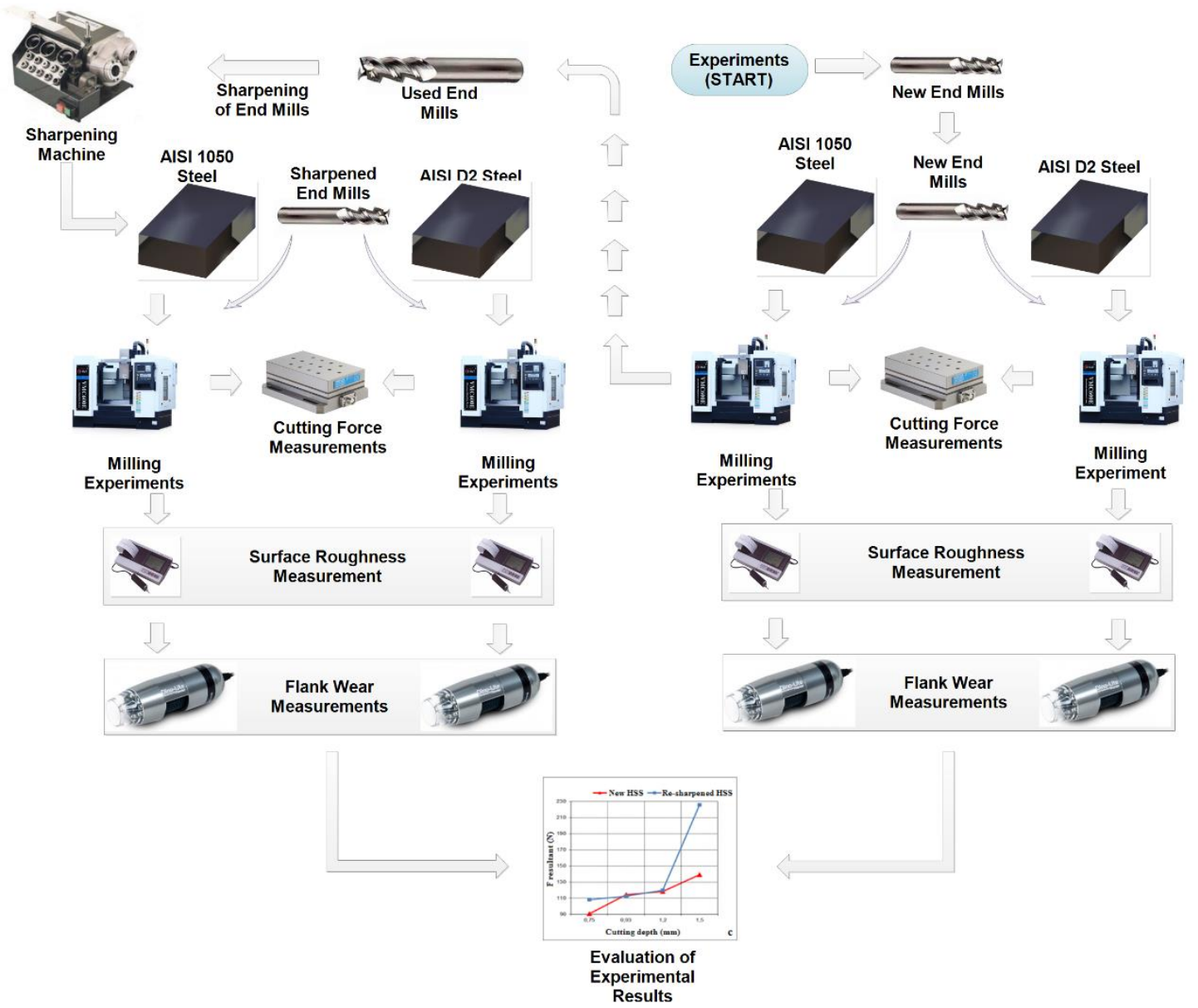

Figure 1. Flow chart of experimental setup

2.1. Material and equipment used in the experimental studies

In the study according to the advice of the tool manufacturing firms, under the specified machining conditions, the results obtained with the new tools and the sharpened tools after subjecting to the same processes were examined by making comparisons. In the experimental studies, machining was made on the AISI 1050 manufacturing steel with HSS end mills having two different diameters (Ø5-Ø8), and another machining was made on the AISI D2 cold work tool steel with carbide mills of Ø5-Ø8 diameter. The material, equipment, machining parameters, tool machine are given below.

The chemical composition of AISI 1050 manufacturing steel and AISI D2 cold work tool steel test samples are given in Table.1. Test variables used in the experimental studies are given in Table.2. 
DEÜ FMD 24(70), 247-262, 2022

Table 1. Chemical composition of test samples (\% max.)

\begin{tabular}{llllllllll}
\hline Material & C & Si & Mn & P & S & Cr & Ni & Mo & Fe \\
\hline AISI 1050 & 0,533 & 0,293 & 10,883 & 0,033 & 0,012 & 0,255 & 0,183 & 0,098 & Other \\
AISI D2 & 1,003 & 0,134 & 0,271 & - & - & 11,88 & 0.193 & 0.693 & Other \\
\hline
\end{tabular}

Table 2. Experimental variables

\begin{tabular}{ll}
\hline Cutting condition & Parameter/Characteristic \\
\hline Cutting tool diameter (mm) & $\emptyset 5-\emptyset 8$, four flute \\
Tool material & $\begin{array}{l}\text { HSS (DIN844/2-1981) } \\
\text { Cementite carbide (97408064) }\end{array}$ \\
Cutting speed (m/min) & $45-56.25-72-90$ \\
Feed rate (mm/tooth) & $0.025-0.03125-0.04-0.05$ \\
Cutting depth (mm) & $0.75-0.93-1.20-1.50$ \\
Cutting length (mm) & 150 mm \\
Number of cutting teeth (item) & 4 \\
Material hardness (HRc) AISI 1050 (C45) & 18 \\
Material hardness (HRc) AISI D2 (2080) & 23 \\
\hline
\end{tabular}

Machining processes were made at $\mathrm{CNC}$ JOHNSFORD VMC-550 vertical machining center which has FANUC control unit that can make linear and circular interpolation in three axes and also programmable in ISO format in metric and inch units. The force data obtained from the tests was taken during machining of the test pieces on the dynamometer connected to the test setup shown in Figure 1. During and after the tests, the apparatus/equipment used for taking/measuring of the cutting force data and characteristics are given in Table.3. İn measuring the surface roughness values, average surface roughness value $\mathrm{Ra}$ was taken into consideration. Surface roughness values were measured by using MAHR-Perthometer-M1 portable surface roughness device. The surface roughness measurements were made as to be perpendicular to the workpiece edge at a sampling length of $4 \mathrm{~mm}$ from the start and end point of the milled surface (Figure 2). In this study, the average of these two measurements was used.

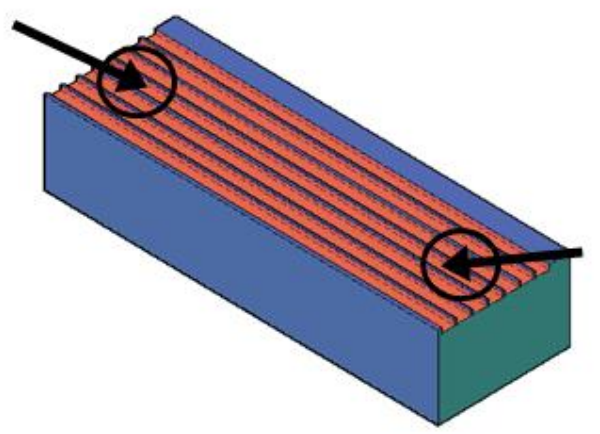

Figure 2. Surface roughness measurement locations

In this study, cutting forces were measured using Kistler 9257B model dynamometer. The experimental setup used for cutting force measurement is shown in Figure 3 and the technical characteristics of the dynamometer are given in Table 3. 


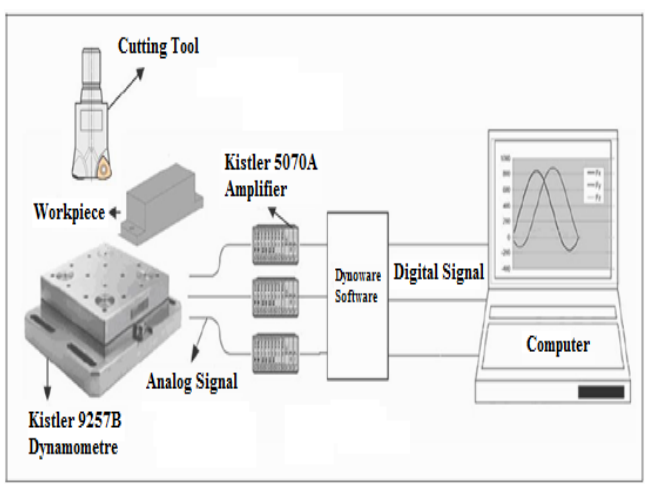

Figure 3. Experimental setup for cutting force measuring

Table 3. Cutting force measuring device/equipment and characteristics

\begin{tabular}{|c|c|}
\hline Device & Characteristic \\
\hline Dynamometer & $\begin{array}{l}\text { Kistler 9257B (Fx, Fy, Fz, } \pm 4 \\
\mathrm{kN} \text {, size: } 170 \times 100 \times 60 \mathrm{~mm})\end{array}$ \\
\hline Amplifier & $\begin{array}{l}\text { Kistler } 5070 \mathrm{~A} \text { (obtaining } \\
\text { data from } 8 \text { channels, } \pm 10 \mathrm{~V} \text { ) }\end{array}$ \\
\hline Data reading card & $\begin{array}{l}\text { CIO DAS } 1602 / 12 \text { Kart ( } 8 \\
\text { analog channel, } 1.25-2.5- \\
510 V \text { measurement } \\
\text { interval) }\end{array}$ \\
\hline Software & Dynoware \\
\hline
\end{tabular}

The force data obtained from the experiments were measured during the processing of the test pieces connected to the dynamometer. Force graphs were generated for each experiment to determine the resultant force of Fx and Fy. For the Fx and Fy components, the average value range was selected from the graph between the input and output and the Fx and Fy components were found. Then the calculated cutting forces of Fx and Fy components were calculated.

HSS and carbide end mills used for the evaluation of the performance of new tools were sharpened with the end mill sharpening machine as shown in Figure 4. Sharpening processes were applied to the face of the cutting tool and after sharpening, tool angles were checked and no changes were observed.

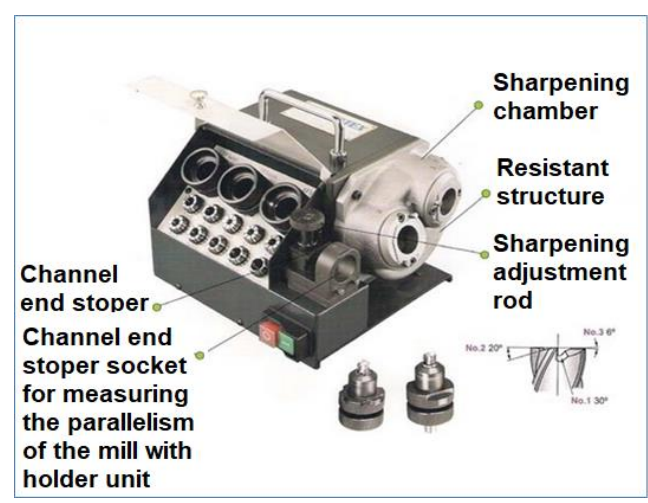

Figure 4. End mill sharpening machine (Vertex catalog)

For the sharpening process, a Vertex VEG-13A end mill sharpening machine with a sharpening diameter of $\emptyset 4 \sim \emptyset 13 \mathrm{~mm}$, power of $450 \mathrm{~W}$ and speed of $6000 \mathrm{rpm}$ was utilized (Figure 4). From the other side, Dino-Lite Pro2 polarized microscope was used for flank wear images of cutting tool. Images were taken at $47.5 \mathrm{x}$ magnification and measurements were made with DinoCapture 2.0 software. An exemplary worn tool image is shown in Figure 5.

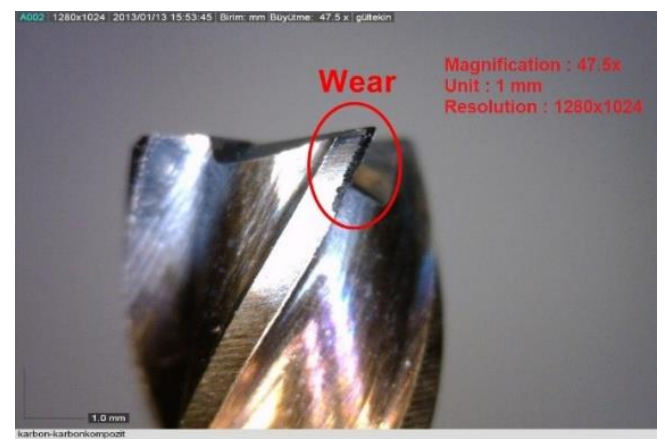

Figure 5. Example of a worn end mill (Magnification: $47.5 \mathrm{x}$ )

Slot milling process was carried out on the material with cutting tools. Slot milling is made side by side on each piece

\subsection{Taguchi experimental design}

In the experimental studies, Taguchi $\mathrm{L}_{16}\left(4^{3} \times 2^{1}\right)$ orthogonal test design was used by specifying suitable factors and levels for the cutting parameters. In Table 4 the obtained experimental factors and levels are given. In Table 5 Taguchi $\mathrm{L}_{16}\left(4^{3} \times 2^{1}\right)$ orthogonal test design is given. 
DEÜ FMD 24(70), 247-262, 2022

Table 4. Experimental factors and levels for HSS and carbide cutting tools

\begin{tabular}{cccccc}
\hline & & \multicolumn{5}{c}{ Levels } \\
\cline { 3 - 6 } Symbol & Cutting parameters & $\mathbf{1}$ & $\mathbf{2}$ & $\mathbf{3}$ & $\mathbf{4}$ \\
\hline A & $\begin{array}{c}\text { Cutting tool diameter } \\
(\mathrm{mm})\end{array}$ & $\emptyset 5$ & $\emptyset 8$ & - & - \\
B & Cutting depth (mm) & 0,75 & 0,93 & 1,20 & 1,50 \\
C & Cutting speed (m/min) & 45 & 56,25 & 72 & 90 \\
D & Feed rate (mm/tooth) & 0,025 & 0,03125 & 0,04 & 0,05 \\
\hline
\end{tabular}

Table 5. Taguchi $\mathrm{L}_{16}$ experimental design for the HSS and carbide cutting tools

\begin{tabular}{|c|c|c|c|c|c|c|c|c|}
\hline $\begin{array}{c}\text { Experiment } \\
\text { no }\end{array}$ & A & B & C & D & A & B & C & D \\
\hline 1 & 1 & 1 & 1 & 1 & $\varnothing 5$ & 0,75 & 45 & 0,025 \\
\hline 2 & 1 & 2 & 1 & 2 & $\varnothing 5$ & 0,93 & 45 & 0,03125 \\
\hline 3 & 2 & 3 & 1 & 3 & $\varnothing 8$ & 1,2 & 45 & 0,04 \\
\hline 4 & 2 & 4 & 1 & 4 & $\varnothing 8$ & 1,5 & 45 & 0,05 \\
\hline 5 & 2 & 2 & 2 & 1 & $\varnothing 8$ & 0,93 & 56,25 & 0,025 \\
\hline 6 & 2 & 1 & 2 & 2 & $\varnothing 8$ & 0,75 & 56,25 & 0,03125 \\
\hline 7 & 1 & 4 & 2 & 3 & $\varnothing 5$ & 1,5 & 56,25 & 0,04 \\
\hline 8 & 1 & 3 & 2 & 4 & $\varnothing 5$ & 1,2 & 56,25 & 0,05 \\
\hline 9 & 1 & 3 & 3 & 1 & $\varnothing 5$ & 1,2 & 72 & 0,025 \\
\hline 10 & 1 & 4 & 3 & 2 & $\varnothing 5$ & 1,5 & 72 & 0,03125 \\
\hline 11 & 2 & 1 & 3 & 3 & $\varnothing 8$ & 0,75 & 72 & 0,04 \\
\hline 12 & 2 & 2 & 3 & 4 & $\varnothing 8$ & 0,93 & 72 & 0,05 \\
\hline 13 & 2 & 4 & 4 & 1 & $\varnothing 8$ & 1,5 & 90 & 0,025 \\
\hline 14 & 2 & 3 & 4 & 2 & $\varnothing 8$ & 1,2 & 90 & 0,03125 \\
\hline 15 & 1 & 2 & 4 & 3 & $\emptyset 5$ & 0,93 & 90 & 0,04 \\
\hline 16 & 1 & 1 & 4 & 4 & $\varnothing 5$ & 0,75 & 90 & 0,05 \\
\hline
\end{tabular}

\section{Experimental Results and Discussion}

3.1 Evaluation of machining performances of new and re-sharpened HSS tools

The data obtained from the machining tests made with HSS tools was evaluated comparatively by considering the resultant cutting force, surface roughness and tool wear for the new and re-sharpened tools. 


\subsubsection{Cutting force}

In the machining tests with a new HSS tool, the changes in the resultant forces created during machining depending on cutting speed, feed rate and cutting depth are shown in the graphs of Figure 6 comparatively with the results obtained with a re-sharpened HSS tool.
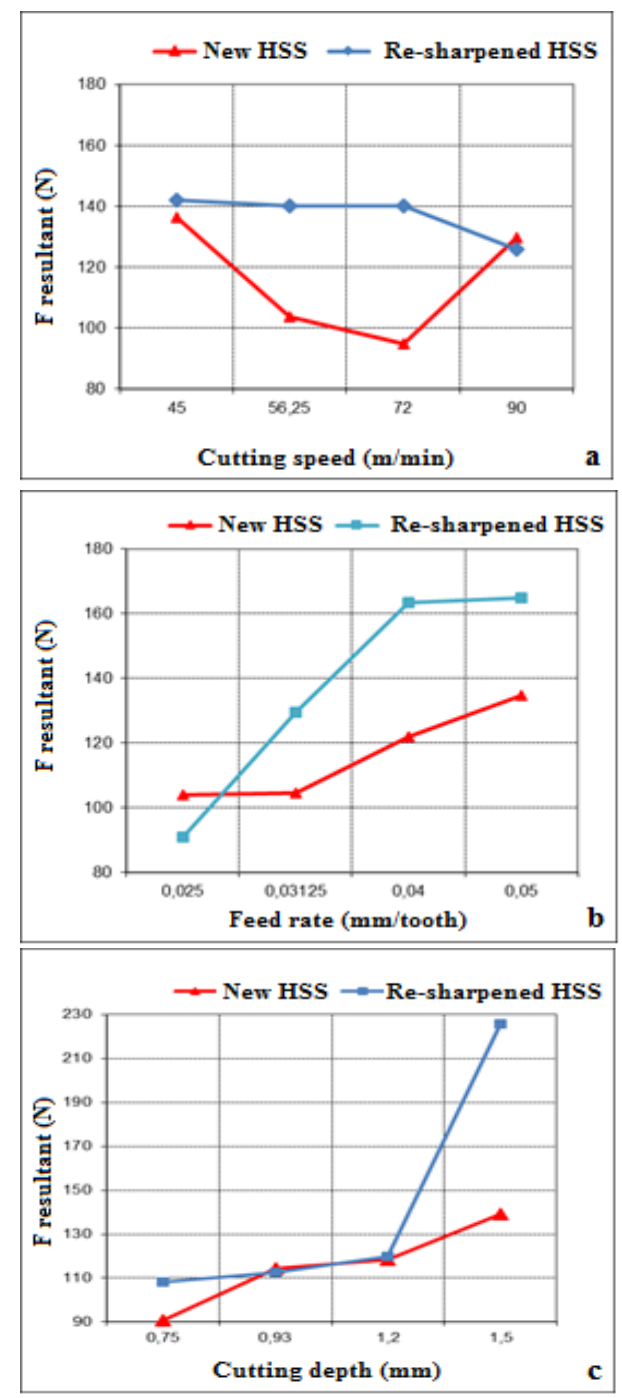

Figure 6. Cutting speed of the resultant force created in machining with HSS tools (a), Feed rate (b) and their variations depending on cutting depth (c).

When the trend of new tool from the graphs in Figure 6 is evaluated it is seen that the resultant force has a tendency to decrease with an increase in cutting speed up to $72 \mathrm{~m} / \mathrm{min}$. This is parallel to literature and is an expected situation and with the increasing cutting speed, the high temperature in the cutting zone is attributed to the easiness of the deformation by assuming that nearly all of the spent energy is converted to heat energy $[4,28]$. With the increase of cutting speed from $72 \mathrm{~m} / \mathrm{min}$ to $90 \mathrm{~m} / \mathrm{min}$, there is a rapid tendency to increase in the resultant cutting speed. This is attributed to the highest average wear $(0,662 \mathrm{~mm})$ reached in the cutting tool for this speed. The amount of wearing observed on the tool at this cutting speed was approximately 1,8 times more than the wear amount observed at the other speeds. It is thought that with the increasing wearing, the increased frictional forces become effective on the resultant forces causing the forces to increase [29]. In the resharpened HSS tools, the variation in the cutting forces depending on the cutting speed exhibited a different tendency than the results obtained with the new tools, (Figure 6a). At the lowest cutting speed $(45 \mathrm{~m} / \mathrm{min})$, while the cutting forces came out to be same for both of the two tools, the decreasing tendency in the cutting tools with the increasing cutting speeds was not observed in the re-sharpened tool and the resultant force almost remained constant $140 \mathrm{~N}$. At low feed rates, longer contact of cutting tool with work piece and increase of heat transfer to tool depending on time caused adverse effects on the cutting tool $[28,29]$. This situation which was resulted with the increased cutting speeds in both new and re-sharpened tools shows the drawbacks of working at lower speeds once more. The expected decreasing tendency in the cutting forces with the increasing cutting speed was not observed and observation of approximately 1,4 times more cutting forces with respect to new tool was attributed to the deviations from ideal geometry after sharpening and increased friction depending on the burrs formed at the re-sharpened sides of the tool. The most remarkable result in the re-sharpened tools was observed at $90 \mathrm{~m} / \mathrm{min}$ and at this speed the cutting force started to decrease and approached the cutting force value of new tool. This situation was commented as the Indication of self-sharpening ability which is desired in the multi point tools such as end mill. With the increasing cutting speed during machining, as a result of the ability of the tool to renew itself and removal of burrs created after sharpening, an 
DEÜ FMD 24(70), 247-262, 2022

ideal (new) geometry is reached and almost nearly the same results of a new cutting tool is obtained. This puts forward the fact that when working with re-sharpened tools, increasing of the desired starting speeds can cause more favorable results.

For both of the two tools there ls a tendency to increase in the resultant forces with the increasing feed rates (Figure 6b). This is a completely expected situation. Basically, the most important component forming the cutting force is chip section area and increasing feed rates cause the cutting forces to increase parallel to the increase in the chip section area $[4,28]$. The tendency of this increase in the resharpened tools was $(0,03125$ and 0,04 $\mathrm{mm} /$ tooth) at the medium feed rates and $125 \%$ $135 \%$ higher with respect to new tools. This can be explained as in the variations depending on cutting speed. After sharpening, deviations from ideal geometry with respect to new tool reflected to the increases in feed rate and cutting forces. Depending on the increase in the highest feed rate $(0,05 \mathrm{~mm} /$ tooth $)$ for the re-sharpened tools the increasing tendency in the cutting forces changed again to decreasing tendency and this was evaluated as the indication of the ability of the tool to renew itself. When this tendency similar to the one in the cutting speed is considered, it is recommended for the resharpened tools to use cutting speed-higher feed rate combinations.

In both of the new and re-sharpened tools the increasing cutting forces (Figure 6c) depending on the increasing cutting depth can be explained similar to the effect of feed rate on the cutting forces. The chip section area depending on the increasing cutting depth is the main cause of increase in the cutting forces [4]. For the first three cutting depths $(0,75-0,93-1,2 \mathrm{~mm})$, the cutting forces observed in the new and resharpened tools came out to be close to each other and this shows that the cutting depth after sharpening has no adverse effect. However, at the highest cutting depth $(1,5 \mathrm{~mm})$, the resultant cutting force $(225,633 \mathrm{~N})$ observed with the resharpened tool was approximately 1,62 times higher than the resultant cutting force $(139,142$ $\mathrm{N})$ observed with the new tool. This result, unlike the sayings on cutting speed and feed rate, puts forward the need to work with the re-sharpened tools with rather lower cutting depth.

\subsubsection{Average surface roughness}

In the machining tests with a new HSS tool, cutting speed, feed rate and variations of average surface roughness ( $\mathrm{Ra}$ ) in the work piece depending on the variations in cutting depth were compared with the results obtained with a re-sharpened tool and are given in graphs in Figure 7.
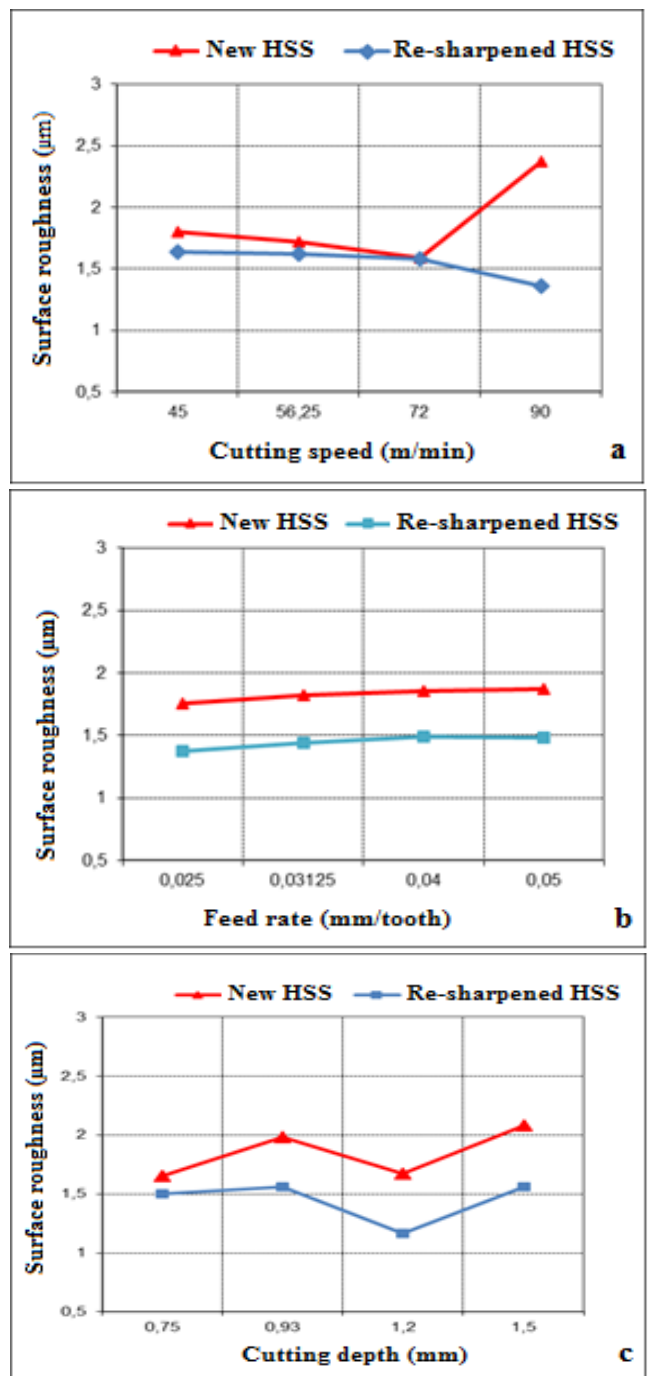

Figure 7. Variations of average surface roughness created by machining using HSS tools depending on cutting speed (a), feed rate (b), and cutting depth (c)

It is known that surface quality gets better with the increase in cutting speed [30]. With the 
increasing cutting speed parallel to the increasing heat in the cutting zone makes the deformation easier and the surface quality is affected favorably. This was observed in the tests for both re-sharpened and new tools except the highest cutting speed (Figure 7a). At the 90 $\mathrm{m} / \mathrm{min}$ cutting speed the increased wear for the new tool reflected to surface quality adversely as in the cutting forces. Whereas on the resharpened tools a favorable progress was observed. With the increasing cutting speed, ability of the geometry after sharpening to renew itself was more effective and unlike the new tool caused to obtain favorable results on the average surface roughness. This remarkable result, as in the cutting forces, shows that working with resharpened tools at high speeds will be more effective from the point of surface quality.

Itis known that feed rate is one of the most effective parameters on the surface quality (from the equation $R_{\max }=$ (f/ 8.r) $x$ 1000), and also surface roughness increases with the increasing feed rate values $[28,30]$. Results obtained from the experimental studies verify this situation (Figure 7b). For both of the new and resharpened tools, depending on the increasing feed rates a worsening was observed in the surface quality. The results of this study showed that the surface quality obtained with the resharpened tools was a bit better than the surface quality with new tools. While the average surface roughness values obtained with new tools were in the interval of $1,758 \mu \mathrm{m}-1,814 \mu \mathrm{m}$, in the resharpened tools it was 1,377 $\mu \mathrm{m}-1,487 \mu \mathrm{m}$. Depending on this relative improvement it can be said that the re-sharpening processes caused negativeness from the point of surface quality.

In Figure $7 \mathrm{c}$ variation in the surface quality depending on the cutting depth is given. The variation observed for both tools is in the same tendency and shows parallelism. Except 1,2 mm cutting depth, average surface roughness increased with the increasing cutting depth. Depending on the working conditions, obtaining a better surface quality at $1,2 \mathrm{~mm}$ cutting depth, points out that this cutting depth can be used as an optimum. As in the effect of both cutting speed and feed rate, obtaining better surface quality in the re-sharpened tools for cutting depth showed that sharpening processes had no adverse effect on the surface quality.

\subsubsection{Tool flank wear}

Variations in the tool flank wear amounts depending on cutting speed, feed rate and cutting depth are given in the graphs of Figure 7. When the graphs in Figure $7 a$ Figure $7 b$ are examined it is seen that wearing tendencies in the cutting tools have similar tendency with the graphs showing the variations in the cutting forces depending on the cutting speed and feed rate in Figure 6. When the graphs are evaluated reciprocally it is possible to say that increased wearing has an adverse effect on the cutting forces and also the increase in the cutting forces affects the wearing behaviors adversely. From the graphs in Figure 8a, b, c it is also observed that the wear amount in the re-sharpened tools is higher than in the new tools. It is thought that this situation is related to how much the first geometry is obtainable after sharpening.
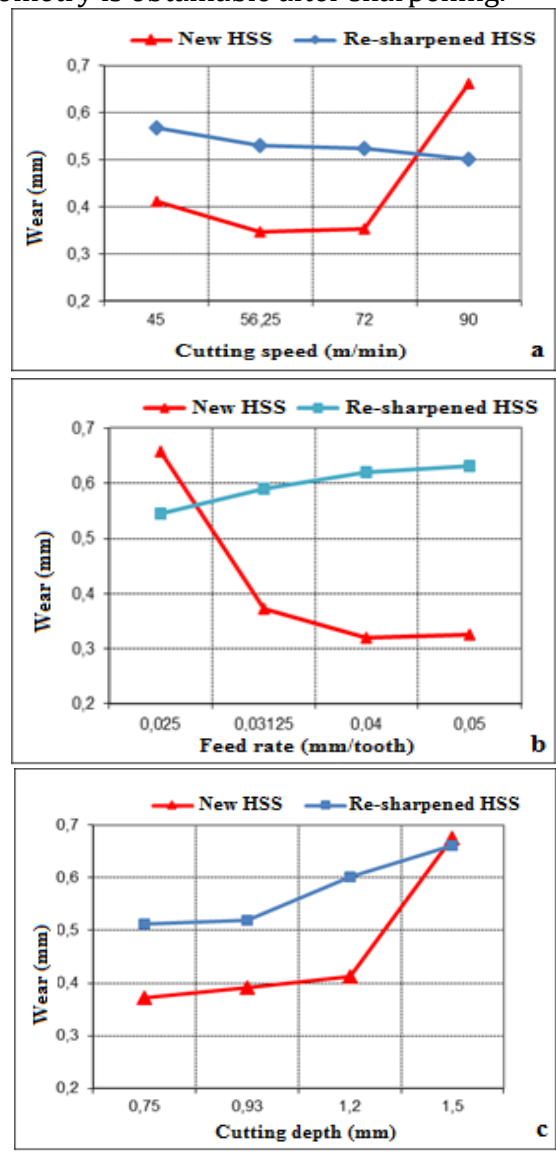

Figure 8. Variations of tool flank wear after machining with HSS tools depending on cutting speed (a), feed rate (b) and cutting depth (c). 
For the cutting speed, feed rate and cutting depth parallel to the increasing values from the starting values the wear behavior did not change significantly and it is thought that in the geometry obtained by sharpening there are still wear marks remained from the previous wearing rather than the adversely affecting of the wear by sharpening. Besides, after sharpening, cleaning was made only with pressured air and the burrs created with sharpening could not possibly be cleaned properly and consequently they might remain along the cutting side as wear mark.

From the graphs in Figure $8 \mathrm{~b}$ it is seen that while the increase in the feed rate has a favorable effect in the wear behavior the same effect is not seen in the re-sharpened tool. Since in the wearing measurements the constant chip volume is taken into consideration, the possible adverse effect of increase on the feed rate did not reflect to the graphs. In the new tools, decreasing tendency in wearing with the increasing feed rate is attributed to the contribution of feed to chip release and consequently to the prevention of cutting the already cut chips again. As for the resharpened tools, the increasing feed rates adversely affect the wear behavior. Since the temperature created during sharpening cannot be controlled, it is thought that it adversely affects the tool material and accelerates the wearing tendency. From the graphs in figure 8c) it is seen that the cutting depth adversely affects the wear. This situation is attributed to the increasing tool-work piece contact duration [18, 28].

\subsection{Evaluation of machining performances of carbide tools}

As a result of the machining tests made with cementite carbide tools the obtained data was comparatively evaluated for the new and resharpened tools.

\subsubsection{Cutting force}

In machining with a new cementite carbide tool, depending on the variation in the cutting speed, feed rate and cutting depth, the comparison of the results with re-sharpened carbide tool and the variation in the resultant force created in machining is shown in the graphs of Figure 9.
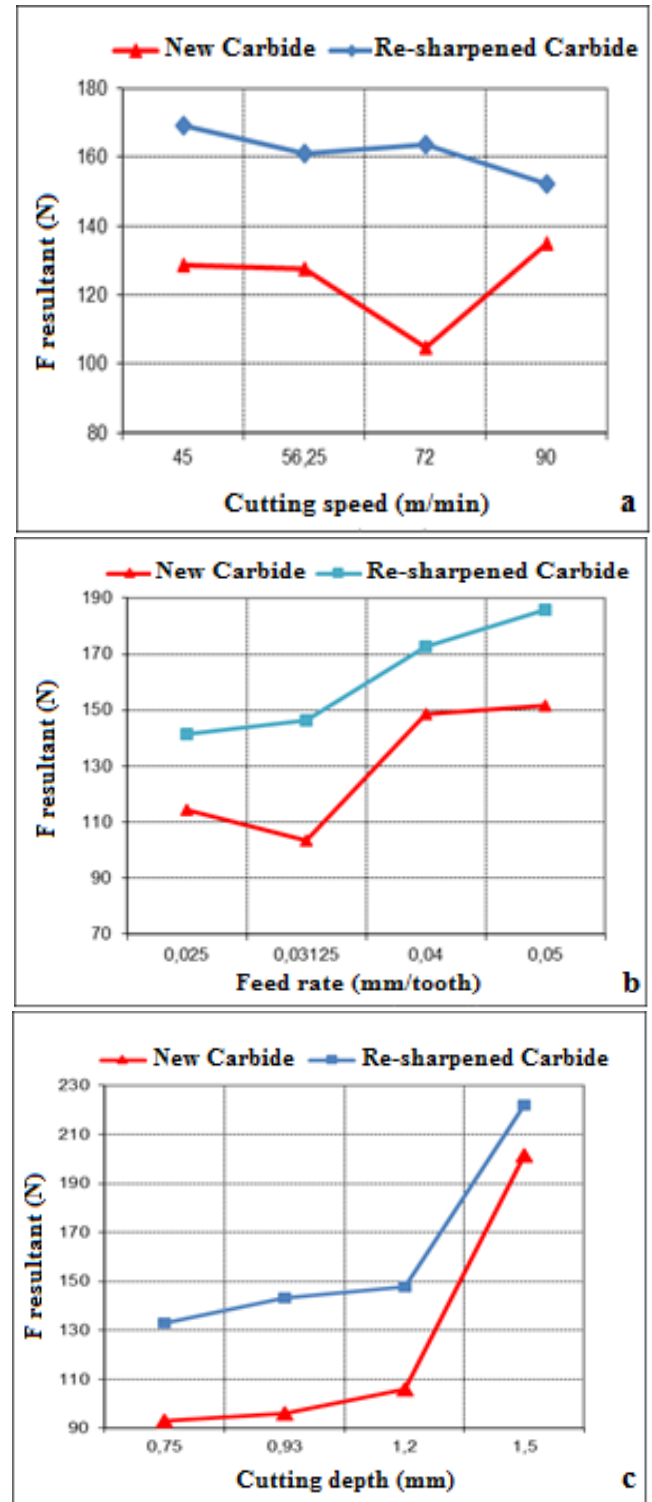

Figure 9. Variations of resultant force created by machining with cementite carbide tools depending on cutting speed (a), feed rate (b) and cutting depth (c).

When the graph of new tool from Figure 8a is evaluated, it is seen that the resultant force have a tendency to decrease with the increasing cutting speed up to $72 \mathrm{~m} / \mathrm{min}$. This situation, as explained for HSS tools, is in conformity with literature and is already so expected $[4,28]$. A rapid increasing tendency in the resultant cutting force is observed with the increasing 


\section{DEÜ FMD 24(70), 247-262, 2022}

cutting speed from $72 \mathrm{~m} / \mathrm{min}$ to $90 \mathrm{~m} / \mathrm{min}$. This situation, as observed also in HSS tools was attributed to the observation of the highest flank wear $(0,360 \mathrm{~mm})$ at this speed. The wear amount in the tool at this speed was approximately 25\% more with respect to the observed wear amount at other speeds. It is thought that frictional forces increase with the increased wear affecting on the resultant forces causing the force to increase [29].

In the re-sharpened carbide tools, variation in the cutting forces depending on the cutting speed did not exhibit a tendency similar to the results obtained with the new tools (Figure 9a). At the lowest cutting speed ( $45 \mathrm{~m} / \mathrm{min})$, the resultant cutting force created on the resharpened carbide cutting tool increased 30\% times of the resultant cutting force created in the new cementite carbide tool. A decreasing tendency was observed in the cutting forces with the increasing cutting speeds. At lower cutting speeds, cutting tool and work piece remain longer in contact and heat transfer to tool increases depending on time and these affect the cutting tool adversely $[28,29]$. This situation in which the cutting forces increase in both resharpened and new tools, again as in the HSS tools, shows once more the drawbacks of working at lower speeds. The most remarkable situation in the re-sharpened tools was observed at $90 \mathrm{~m} / \mathrm{min}$ cutting speed. At this speed cutting force has a decreasing tendency and approached to cutting force observed with the new tool. This situation was commented as an indication of ability of self-sharpening desired in the multi point tools such as end mill. This puts forward once more that when working with resharpened tools, increasing the wanted starting speeds a bit more exhibits more favorable results.

It is seen for both of the tools that there is an increasing tendency in the resultant cutting forces with the increasing feed rates (Figure 9b). This increasing tendency in re-sharpened tools were higher at the medium feed rates $(0,03125$ and $0,04 \mathrm{~mm} /$ tooth) with respect to the new tools. This can be explained as in the variations depending on cutting speed. After sharpening, deviations from ideal geometry with respect to the new tool reflected also to the increase observed in cutting forces with the increasing feed. Depending on the increase in the highest feed rate $(0,05 \mathrm{~mm} /$ thread $)$ for re-sharpened tools, changing of the cutting forces from increasing tendency to decreasing tendency again was evaluated as the indication of ability of the tool to renew itself. When this tendency similar to the tendency in the cutting speed was considered, as advised for the HSS tools, it is advised to use feed rates having rather high cutting speed when working with re-sharpened solid cementite carbide tools as well.

The increasing cutting forces depending on the increasing cutting depth in both new and resharpened tools (Figure 9c) can be explained similar to the effect of feed rate on the cutting forces. Chip section area which is related to the increasing cutting depth is the main cause of increase in the cutting forces [28]. The cutting forces observed in both of the new and resharpened tools for the first three cutting depths $(0,75-0,93-1,2 \mathrm{~mm})$ came out to be close to each other showing that the cutting depth after sharpening has not any adverse effect. However at the higher cutting depth of $1,5 \mathrm{~mm}$, the resultant cutting force observed with resharpened tool $(222,165 \mathrm{~N})$, has become approximately $10 \%$ higher than the resultant cutting force $(201,322 \mathrm{~N})$ observed with the new tool. This result, unlike the sayings about cutting speed and feed rate, puts forward the need to work with re-sharpened tools with rather lower cutting depth.

\subsubsection{Average surface roughness (Ra)}

Variations of average surface roughness of the machined surface depending on the cutting speed, feed rate and cutting depth are given in the graphs of Figure.10.

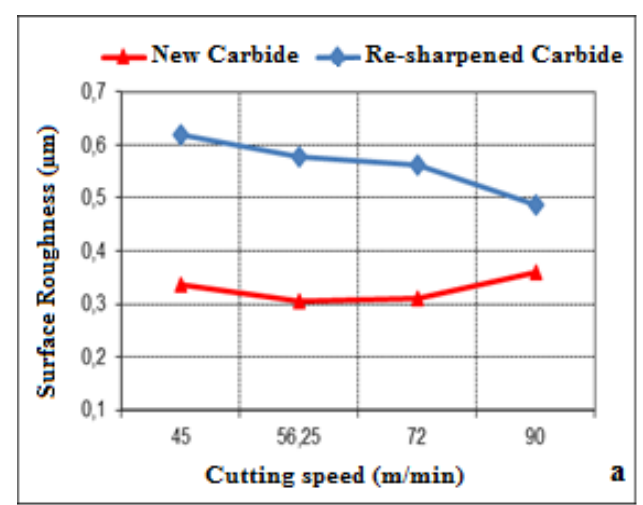



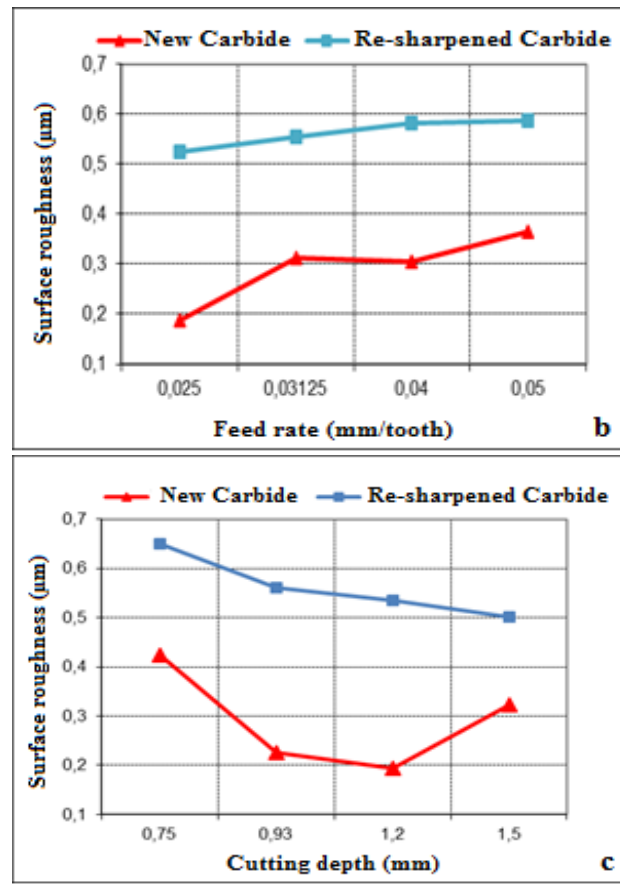

Figure 10. Variations of average surface roughness created by machining with cementite carbide tools depending on cutting speed (a), feed rate (b) and cutting depth (c).

Improvement of surface quality with the increasing cutting speed was also stated before [30]. When the graphs in Figure 10a) are examined, with the increasing cutting speed parallel to the increasing heat in the cutting zone, deformation becomes easier and reflects to surface quality favorably. This situation was observed in the tests both for the new and resharpened tools except the highest cutting speed (90 $\mathrm{m} / \mathrm{min})$. At the $90 \mathrm{~m} / \mathrm{min}$ cutting speed the wear amount for the new tool, was reflected adversely to the surface quality as in the cutting forces. Whereas in the re-sharpened tools a favorable progress was observed in the surface quality with a tendency similar to the one in cutting forces. With the increasing cutting speed, ability of the geometry to renew itself was more effective and unlike the new tool, caused to obtain favorable results on the average surface roughness. This result, as in the cutting forces, shows that working with re-sharpened tools at rather higher speeds will be more effective from the point of surface quality.
It is known that the feed rate is one of the most effective parameters on surface quality $[28,30$, $31]$. The obtained data from the experimental studies (Figure 10b) proves it. Depending on the increasing feed rates a worsening was observed in the surface quality for both of the new and resharpened tools. According to the results from this study, when the highest average surface roughness values were compared with respect to the increasing feed rate it was seen that resharpened carbide cutting tool gave $60 \%$ worser result compared to the new carbide cutting tool. When the starting and sharpening costs of carbide tools are considered, especially from the point of surface quality, using new tools are advised rather than re-sharpened ones for small diameter tools. However, for greater diameter the cost increases and in this case re-sharpening can be advised with the condition of observing the variation in surface quality.

Variation in the surface quality depending on the cutting depth for both of the tools up to $1,2 \mathrm{~mm}$ cutting depths were in the same tendency and exhibited parallelism (Figure 10c). Depending on the working conditions, obtaining a better surface quality at the $1,2 \mathrm{~mm}$ cutting depth for the new carbide tool shows that this cutting depth can be optimally used. However, while the average surface roughness value increases in the new carbide tool at 1,5 mm cutting depth, it decreases in the re-sharpened carbide tool. This can be explained in such a way that, carbide tools are manufactured by powder metallurgy and after sharpening, getting the ideal smoothness at the re-sharpened cutting sides is more difficult compared to HSS tools sharpening.

\subsubsection{Tool flank wear}

Variations in the tool flank wear amounts depending on cutting speed, feed rate and cutting depth are given in Figure 10. When the graphs in Figure 11a are reciprocally evaluated it can be said that similar to HSS tools, increased wearing has an adverse effect on cutting forces and the increase in the cutting forces causes an increase in the wearing behaviors. It is seen that wear amount in the re-sharpened tools is higher with respect to the new tools. It is thought that this is related to how much the first geometry is obtainable after sharpening.

There is not a significant variation in the wear behavior parallel to the increasing values from 


\section{DEÜ FMD 24(70), 247-262, 2022}

the starting values for the cutting speed, feed rate and cutting depth and this may be due to non-removal of wear marks remained from the old wear in the geometry obtained by sharpening rather than the effect of adversely wearing of sharpening. As was explained previously, after sharpening, cleaning with only pressured air shows the possibility that the burrs created during sharpening may not be cleaned completely and remain along the cutting sides as wear marks.
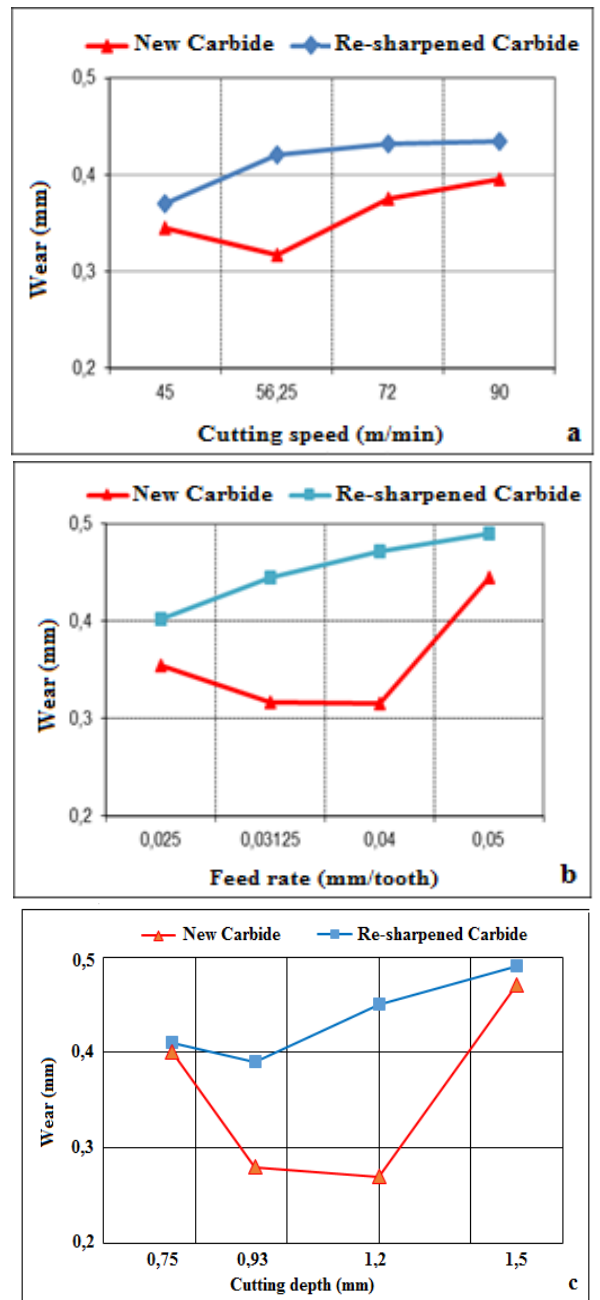

Figure 11. Variations tool flank wear (VB) after machining with cementite carbide tools depending on cutting speed (a), feed rate (b) and cutting depth (c).
While the increase in feed rate has generally a favorable effect on wear behavior for the new tool, the same effect is not observed in the resharpened tool (Figure 11b). In the wear measurements, since constant chip volumes are taken into consideration, the possible adverse effect of increase in the feed rate did not reflect to the graphs. In the new tools, the decreasing tendency in wearing with the increasing feed rate was attributed to the contribution of feed rate to the chip release and to the prevention of cutting of the previously cut chips again. As for the re-sharpened tools, the increased feed rates affect the wear behavior adversely and when the average feed rate value $(0,04 \mathrm{~mm} /$ thread $)$ is considered, wear amount in the re-sharpened tools was $60 \%$ more than the wear amount in the new tools. The temperature created after sharpening cannot be controlled and it is thought that this temperature affects the tool material adversely and accelerates the wear tendency. When the graphs in Figure. 11b are examined, while the increase in the feed has generally a favorable effect on wear behavior for the new tool it is seen that it doesn't have the same effect in the re-sharpened tool. In the wearing measurements since the constant chip volume is taken into consideration, the possible adverse effect of increasing feed rate on wearing did not reflect to the graphs. In the new tools, tendency to decrease in wearing with the increasing feed rate, was attributed to the contribution of feed rate to the chip release and consequently to the prevention of cutting of the already cut chips again. As for the re-sharpened tools it is considered that the increased feed rates adversely affect the wear behavior and When the average feed rate value is taken as $(0,04$ $\mathrm{mm} /$ thread) it is seen that the wear amount in the re-sharpened tools is approximately 1,6 times the wear amount in the new tool. When the graph in Figure 11c is examined, it is seen that the depth of cut affects the wear negatively. This situation is attributed to the increased length of the tool-work piece contact area [19, 28].

\section{Conclusion}

In this study, performances of reused HSS and solid Cementite Carbide End Mills by resharpening was investigated. The results obtained in the study are summarized below:

- As a result of the machining tests made with HSS and solid cementite carbide cutting 


\section{DEÜ FMD 24(70), 247-262, 2022}

tools, depending on the increase in the cutting speed, a decreasing tendency in the resultant cutting force was observed expectedly in the new tools up to $90 \mathrm{~m} / \mathrm{min}$ and at $90 \mathrm{~m} / \mathrm{min}$ cutting speed cutting forces had a tendency to decrease again. This increase was attributed to the higher flank wear measured in both types of the new tools.

In the re-sharpened HSS and carbide cutting tools, the increase in the cutting speed was less effective on the resultant cutting forces compared to new tools. The most remarkable result was obtained in the new tools at the $90 \mathrm{~m} / \mathrm{min}$ cutting speed when the greatest resultant force has been observed. In the resharpened tools, at this speed, unlike the new tools, cutting forces had the tendency to decrease at this speed. This situation was attributed to the increasing ability of the tool to renew itself after sharpening

- When the effect of three cutting parameters (cutting speed, feed rate and cutting depth) on the resultant cutting forces is evaluated, while, with the re-sharpened tools, it is advised to work with rather high cutting speed-feed combinations, it is recommended to keep the cutting depth shorter.

- While the increase in the cutting speed had a favorable effect on the surface quality in all of the cutting tools whereas in the new cutting tools at the highest cutting speed of $90 \mathrm{~m} / \mathrm{min}$, the increasing wear amount reflected adversely on the surface quality. Similar to the effect of cutting speed on the resultant cutting forces, the best surface quality with the re-sharpened tools was observed at the highest cutting speed of 90 $\mathrm{m} / \mathrm{min}$. This shows that working with the resharpened tools at rather high speeds will exhibit favorable results on the surface quality.

- The increase in the feed rate affected the surface quality adversely for all of the tools. It was attributed to the effects of feed rate on the surface roughness as known from the literature.

In general, in the new and re-sharpened tools, the best surface quality was obtained at the $1.2 \mathrm{~mm}$ cutting depth. It shows that vibrations created during machining can be tolerated at this cutting depth.

- In the HSS tools, sharpening has no adverse effect on the surface quality and in general, exhibits better results with respect to new tools but the surface roughness obtained with re-sharpened cementite carbide tools came out to be higher compared to the new cutting tools. It was attributed to the higher ability of HSS tools to renew themselves.

- It was observed that wear amounts in the resharpened tools were more than the ones in the new tools. It was attributed to the fact that the ideal geometry could not be completely obtained by sharpening and there was the adverse effect of burrs after sharpening.

- Since there was not any adverse effect of sharpening on machining performance in HSS tools, their usage after sharpening can be recommended.

- For the solid cementite carbide tools; by considering the relationship of first and after sharpening costs, while sharpening is advised especially for small diameter tools from the point of surface quality (when the increasing tool cost is considered parallel to increase in diameter) re-sharpening may be advised with the condition of observing the expectations in the surface quality.

\section{Acknowledgement}

This project is supported by Gazi University Research Fund Project Number: 07/2012-51. The authors would like to thank the Gazi University, Department of Scientific Research Projects, Ankara, Turkey, for financially supporting this research.

\section{References}

[1] Domaç, H. 2010. Frezeleme İşleminde Kesici Uç Yarıçapı ve Uç Geometrisinin Yüzey Pürüzlülüğü ve Kesme Kuvvetleri Üzerindeki Etkilerinin Araştırılması, Gazi Üniversitesi Fen Bilimleri Enstitüsü, Yüksek Lisans Tezi, 10s, Ankara

[2] Tonshoff, H. L., Spintig, W., Konig, W., Neises, A. 1994. Machining of Holes Developments in Drilling Technology, Annals of the CIRP, Cilt. 43(2), s. 551560.

[3] Diniz, A. E., Filho, J. C. 1999. Influence of The Relative Positions of Tool And Workpiece on Tool 


\section{DEÜ FMD 24(70), 247-262, 2022}

Life, Tool Wear and Surface in The Face Milling Process, Wear, Cilt. 232(1), s. 67-75.

[4] Boothroyd, G., Knight, W.A. 1989. Fundamentals of Machining and Machine Tools, Second Edition. Marcel Dekker Inc. Cilt 5, s. 212-222.

[5] Ghani, J. A., Choudhury, A., Masjuki, H.H. 2004. Performance of P10 Tin Coated Carbide Tools When End Milling AISI H13 Tool Steel at High Cutting Speed, Journal of Materials Processing Technology, Cilt. 153-154, s. 1062-1066.

[6] Budak, E., Altındaș, Y., Armegedo, E.J.A. 1996. Prediction of End Milling Force Coefficients from Orthogonal Cutting Data, ASME J. of Manufacturing Science and Engineering, Cilt. 118, s. 216-224.

[7] Korkut, İ., Dönertaș, M.Ö. 2007. The Influence of Feed Rate and Tool-Chip Contact Length During Face Milling, Material \& Design, Cilt. 28(1), s. 308312.

[8] Zhang Julie, Z., Chen Joseph, C., Kirby, E.D. 2007. Surface Roughness Optimization in An End-Milling Operation Using the Taguchi Design Method, Journal of Materials Processing Technology, Cilt. 184(1-3), s. 223-239.

[9] Gökkaya, H., Sur, G., Dilipak, H. 2006. Kaplamasız Sementit Karbür Kesici Takım ve Kesme Parametrelerinin Yüzey Pürüzlülüğüne Etkisinin Deneysel Olarak İncelenmesi. Pamukkale Üniversitesi Mühendislik Fakültesi Dergisi, Cilt. 12(1), s. 59-64.

[10] Güllü, A., Özdemir, A. 2003. Experimentally Determination of The Relationship Between Surfaces Roughness and The Cutting Parameters in Milling of The Prismatic Parts, Gazi University Journal of Science, Cilt. 16(1), s. 127-134.

[11] Jawaid, A., Sharif, S., Koksal, S. 2000. Evaluation of Wear Mechanisms of Coated Carbide Tools When Face Milling Titanium Alloy, Journal of materials processing technology, Cilt. 99(1-3), s. 266-274.

[12] Chou, Y.K., Song, H. 2001. Hard Turning with Different Nose-Radius Ceramic Tools, SME Tech. Pap. Ser., s. 13-26.

[13] Yang, W.H., Tarng, Y.S. 1998. Design Optimization of Cutting Parameters for Turning Operations Based on The Taguchi Method, Journal of Materials Processing Technology, Cilt. 84(1-3), s. 122-129.

[14] Kopač, J., Bahor, M., Soković, M. 2002. Optimal Machining Parameters for Achieving the Desired Surface Roughness in Fine Turning of Cold PreFormed Steel Workpieces, International Journal of Machine Tools and Manufacture, Cilt. 42(6), s. 707 716.

[15] Choudhury, S.K., Bartarya, G. 2003. Role of Temperature and Surface Finish in Predicting Tool Wear Using Neural Network and Design of Experiments, International Journal of Machine Tools and Manufacture, Cilt. 43(7), s. 747-753.
[16] Davim, J.P., Gaitonde, V.N., Karnik, S.R. 2008. Investigations into The Effect of Cutting Conditions on Surface Roughness in Turning of Free Machining Steel by ANN Models, Journal of Materials Processing Technology, Cilt. 205 (1-3), s. 16-23.

[17] Jawaid, A., Köksal, S., Sharif, S. 2001. Cutting Performance and Wear Characteristics of PVD Coated and Uncoated Carbide Tools in Face Milling Inconel 718 Aerospace Alloy, Journal of Materials Processing Technology, Cilt. 116 (1), s. 2-9.

[18] Rajeev, D., Dinakaran, D., Singh, S.C.E. 2017. Artificial neural network-based tool wear estimation on dry turning processes of AISI 4140 steel using coated carbide tool, Bulletin of the Polish Academy of Sciences, Technical Sciences, Cilt. 65(4), S. 553-559.

[19] Sivaiah, P., Chakradhar, D. 2019. Performance Improvement of Cryogenic Turning Process During Machining of 17-4 PH Stainless Steel Using Multi Objective Optimization Techniques, Measurement, Cilt. 136, s. 326-336.

[20] Arulkirubakaran, D., Senthilkumar, V., Lomesh Chilamwar, V., Senthil, P. 2019. Performance of Surface Textured Tools During Machining of Al$\mathrm{Cu} / \mathrm{Tib}_{2}$ Composite, Measurement, Cilt. 137, s. 636646.

[21] Shokrani, A.V., Dhokia, Newman S.T. 2017. Hybrid Cooling and Lubricating Technology for CNC Milling of Inconel 718 Nickel Alloy, Procedia Manufacturing, Cilt. 11, s. 625-632.

[22] Kara, F. 2018. Optimization of Surface Roughness in Finish Milling of AISI P20+S Plastic-Mold Steel, Materiali in Tehnologije/Materials and Technology, Cilt. 52(2), s. 195-200.

[23] Çiftçi, İ., Gökçe, H. 2019. Optimisation Of Cutting Tool and Cutting Parameters in Machining of Molybdenum Alloys Through the Taguchi Method, Journal of the Faculty of Engineering and Architecture of Gazi University, Cilt. 34(1), s. 2012013.

[24] Das, R., Mohanty, S. S., Panigrah, M., Mohanty, S. 2018. Predictive Modelling And Analysis Of Surface Roughness In CNC Milling Of Green Alumina Using Response Surface Method And Genetic Algorithm, IOP Conf. Series: Materials Science and Engineering, s. 410: 1-11.

[25] Nghiep, TN, Sarhan, A. A. D., Aoyama, H. 2018. Analysis of tool deflection errors in precision CNC end milling of aerospace Aluminum 6061 T6 alloy, Measurement, Cilt. 125, s. 476-495.

[26] Böhler Sert Maden ve Takım Sanayi ve Ticaret A.Ş. 1990. Talaş kaldırma bilgileri, Yeni Karar Yayıncılık, İstanbul, s. 31-42.

[27] Şahin, Y. 2000. Talaş kaldırma prensipleri, Nobel Yayın Dağıtım, Ankara, s. 163-170. 
DEÜ FMD 24(70), 247-262, 2022

[28] Şeker, U. 2010. Talaş kaldırma Prensipleri Ders Notları, Ankara.

[29] Trent, E.M. 1989. Metal cutting, Butterworths Press, London, s. 1-171.

[30] Sandvik Coromant, Modern Metal Cutting, 2008. Sandvikens Tryckeri, Sweden, s. 1-6.

[31] Sandvik Coromant, Sandvik Coromant El Kitabl, 2005. Talaşıı İmalat Teknik Kılavuzu. Türkçe Basım, Elanders, İsveç, D5-D9. 